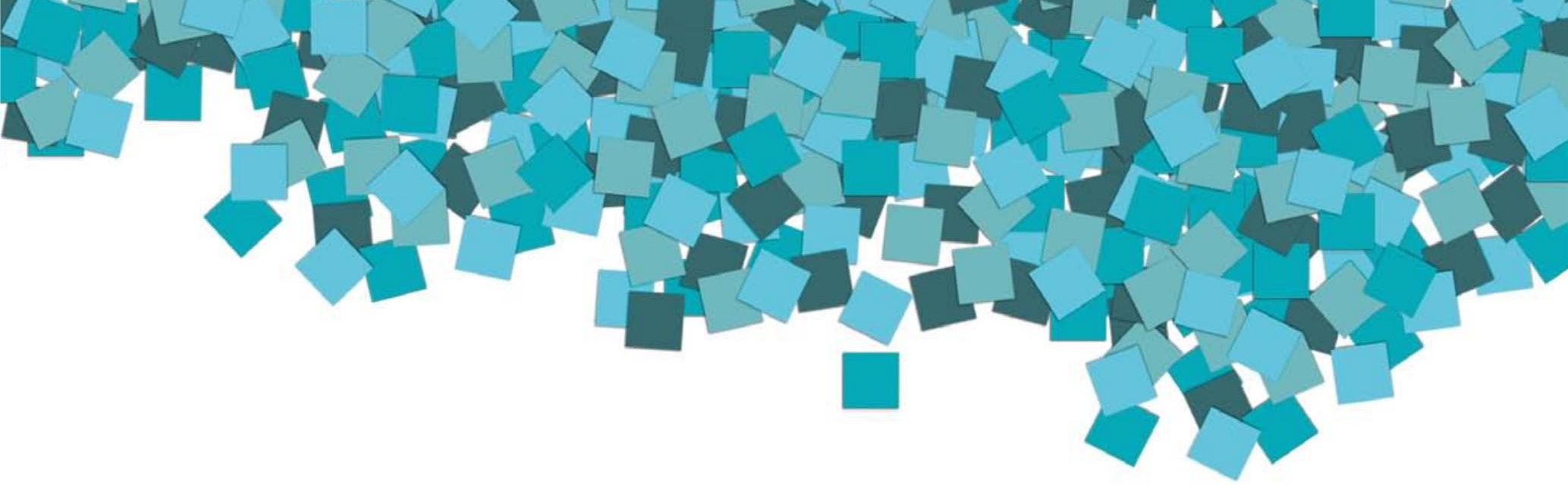

\title{
Journal of Conflictology
}

\section{Table of Contents}

\section{Articles}

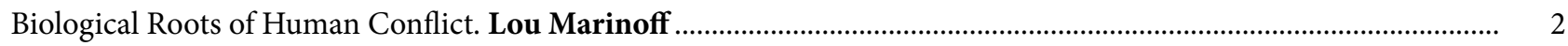

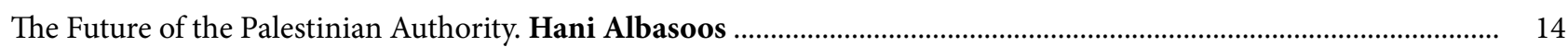

Pacifying Cyberspace in the Age of the Zettabyte. Tom Woodhouse ............................................................................... 23

Girl-Child Education in Post-War Sierra Leone. Kelechi Johnmary Ani and Chukwuma Osakwe ............................ 31

Fundamental Consequences of the Ethio-Eritrean War [1998-2000]. Wuhibegezer Ferede Bezabih........................... 39

A Brief Introduction to Transrational Peace Research and Elicitive Conflict Transformation. Wolfgang Dietrich ...... 48

Elicitive Conflict Mapping: A Practical Tool for Peacework. Josefina Echavarría Álvarez

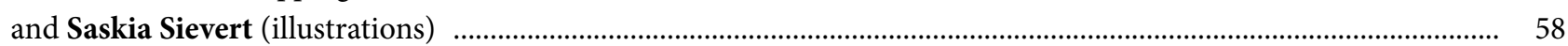

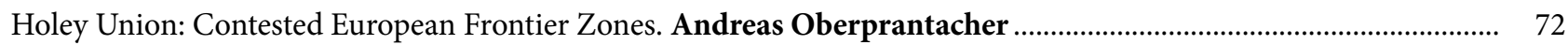

Law as Transformative Conflict Work - A Transrational Approach. Florencia Benítez-Schaefer.................................. 81 